DOI: $10.21554 / \mathrm{hrr} .041910$

\title{
PERCEPTION OF PARENTAL SUPPORT BY DEAF AND HARD-OF-HEARING STUDENTS
}

\author{
Meliha Povlakić Hadžiefendić ${ }^{1}$ \\ Esad H. Mahmutović \\ Husnija Hasanbegović
}

\author{
Original scientific paper
}

Center for Hearing and Speech Rehabilitation, Sarajevo, Bosnia and Herzegovina

Center for Education and Rehabilitation of hearing and speaking Tuzla, Bosnia and Herzegovina Faculty of Education and Rehabilitation, University of Tuzla, Bosnia and Herzegovina

\begin{abstract}
The aim of the paper was to determine the perception of parental support and understanding by deaf and hard-of-hearing students. The sample consisted of 47 deaf and hard-of-hearing students, both genders, with an average age of $16 \pm 1.27$ years. Children's Perceptions of Parents Scale, (Grolnick, Ryan \& Deci, 1991), which consists of three subscales, and which measure parental involvement, support of autonomy and parental warmth, especially for the mother, especially for the father was used in this research. The data were processed by descriptive analysis, and the t-test was used to test the mother's support perception difference in relation to father's support perception. The results showed that deaf and hard-of-hearing students mostly positively perceived the parent involvement, support of autonomy and warmth of both parents, but a statistically significant difference in the individual perception of parents was found in favor of the mothers.
\end{abstract} Keywords: perception, parental support, deaf, hard-of-hearing

\section{INTRODUCTION}

The presence of hearing loss in childhood puts a child at risk for language, social, and academic difficulties. It can negatively affect the quality of life, even if the hearing loss is mild (Burkey, 2006; see Andreeva, Celo, \& Vian, 2017).

Becker, Flower, Glass and Newcomer (1984) according to Olaosun and Ogundiran (2013), argue that hearing loss limits a person's ability to interact with his environment and socially with family and friends and to receive and interpret information in the environment.
The delays in language and socioemotional development are often attributed to delayed identification of deafness, limited provision of early intervention services, and reduced degree of family involvement (Magnuson, 2000; Moeller, 2000; Yoshinaga-Itano \& Apuzzo, 1998; Yoshinaga-Itano et al., 1998; see Kushalnagar, Krull, Hannay, Mehta, Caudle, \& Oghalai, 2007).

Prizant and Meyer (1993) and Baltaxe (2001) according to Nicholas and Geers (2006) argue that poor language skills and/or poor parent-child communicative interactions early in life are associated with concurrent socioemotional and behavioral problems.

\section{Correspodence to:}

Meliha Povlakić Hadžiefendić, Center for Hearing and Speech Rehabilitation, Sarajevo, Bosnia and Herzegovina

Asima Ferhatovića 2, Sarajevo 71000, Bosnia and Herzegovina

Phone:+38761635290

E-mail: melihapovlakicotmail.com 
"When communication at home is not accessible, the youth experiences a social barrier and has difficulty participating in conversations with their parents. This barrier in the youth's home environment can result in adverse impacts on the youth's overall socioemotional well-being" (Kushalnagara, Topolski, Schick, Edwards, Skalicky, \& Patrick, 2011, p. 513).

The first three years in a child's life are critical for acquiring information about the world, communicating with family, and developing a cognitive and linguistic foundation from which all further development unfolds. If a child is able to develop age-appropriate spoken language skills, he or she will be more likely to be prepared to enter a preschool or kindergarten setting ready to participate fully in all activities and to engage in meaningful social interactions with teachers and peers (Hart \& Risley, 1995; see Nicholas \& Geers, 2006).

„The presence of deafness in a family has the potential to affect all areas of family life. An understanding of the impact on family life is critical to addressing all components of the family system in early intervention“ (Jackson, \& Turnbull, 2004, p. 15).

Parents who have accepted their children's differences were more likely to adapt better than parents who experienced emotional struggles in accepting perceived disabilities in their children (Meadow-Orlans, Smith-Gray, \& Dyssegaard, 1995; Watson, Henggeler, \& Whelan, 1990; see Kushalnagar et al., 2007). The ability to reframe a situation in a more positive light, finding meaning in the parenting experience, and parent empowerment are associated with positive gain and reduced parental distress (Minnes, Perry, \& Weiss, 2015; see Szarkowski, \& Brice, 2016).

The research results Hintermair (2006) show that „high parental stress is associated with frequent socioemotional problems in the children, thus emphasizing the importance of a resource-oriented consulting and support strategy in early intervention, because parental access to personal and social resources is associated with significantly lower stress experience. Child development seems to profit enormously from a resource-oriented support concept."

The research results Ahlert and Greeff (2012) showed that ,family time and routines, social support, affirming communication, family hardiness, problem-solving skills, religion, a search for meaning, and acceptance of the child's hearing status were associated with family resilience. Strengthening these elements helps fam ilies to grow, meet challenges, and reestablish balance and harmony within the family system." Many participants in Reiff et al. (1995) study em- phasized the importance of emotional support and social connectedness that continued from childhood into adulthood. Participants reported that their parents persevered through external challenges, such as educators' discriminatory behaviors and low expectations. Parents helped instill a value system consisting of proactive lifestyle practices that led to proactive professional and social outcomes for their children (Jacobs, 2010).

The development of a supportive and warm, caring relationship between a parent and a child can be the first step in strengthening students' perceptions of their own abilities and improving their understanding of learning (Marchant, Paulson, \& Rothlisberg, 2001; see Sremić and Rijavec, 2010).

Parental support, appropriate educational style and parent involvement, degree of support and control are positive factors in the development of self-esteem, social skills development and competence, motivation and school achievement.

The aim of this paper was to determine the perception of parental support and understanding by deaf and hard-of-hearing students.

\section{METHODS}

\section{The sample}

The sample consisted of 47 hearing impaired students $30(63.8 \%)$ deaf and 17 (36.2\%) of hard-of-hearing students), 24 (51.1\%) males and 23 (48.9\%) females, average age of $16 \pm 1.27$ years.

\section{Measuring instrument}

The Children's Perceptions of Parents Scale (Grolnick, Ryan, \& Deci, 1991) used for the examination consisted of three subscales: perceived parental involvement, perceived parental support to autonomy and perceived parental warmth, especially for the mother, especially for father. The total number of claims pertaining to the mother is 21 , and the same for the father as well.

The estimate is done on a Likert-type scale from 1 to 7 (1 - I completely disagree, 7 - I fully agree). Cronbach's alpha coefficient (Cronbach's $\alpha=.87$ ) showed very good reliability and internal scale approval for this sample. The results of the responses were summarized and the total value was obtained, as the basic statistical sequence for the processing and interpretation of the results, which could amount a minimum of 21 and a maximum of 147 points. 


\section{Data analysis}

Data was processed in SPSS program for Windows. The data were processed by descriptive analysis, and the t-test was used to test the mother's support perception difference in relation to father's support perception.

\section{RESULTS AND DISCUSSION}

Frequencies and responses to individual statements indicate that deaf and hard-of-hearing students mostly positively perceive involvement, autonomy support and mothers warmth (Table 1).

In involvement, they mostly find that mothers find time to talk (91.4\%) and spend enough time with them $(85.1 \%)$, and that they are investing time and energy in helping them (82.9\%). About half of them believe that mothers are often too busy to deal with them, and most of them believe that mothers are not much reliant on their concerns $(63.9 \%)$ and do not think too often about them (76.6\%). Students in this case were unlikely to understand that these claims re- late to the involvement of mothers in their activities, rather than their feelings - emotions, as confirmed by positive responses to mother's warmth claims.

In support of autonomy, deaf and hard-of-hearing students mostly feel that mothers know how they feel (97.2\%), allow them to do what they want (61.7\%), listen to their opinion and attitude when they have a problem $(91.5 \%),(65.9 \%)$, they are ready to look through a children's perspective $(78.7 \%)$, help them choose their own path $(72.3 \%)$, but try to determine their way of life $(87.3 \%)$ and to the smallest extent they think they are not too sensitive to their needs $(48.9 \%)$ and to insist on doing things in their (mothers) own way $(55.2 \%)$.

In the case of warmth perceptions, most of them declare that their mothers accept and love them for what they are $(97.9 \%)$, that they express their love for them (95.7\%), make them feel special (85.0\%), usually are happy to see them (91.5\%), and at the lowest rate they often disagree with them (59.6\%) and do not accept their opinion. However, $80.1 \%$ of respondents said that they felt that their mother was disappointed in them.

Table 1. Distribution of responses to perception of involvement, support of autonomy and mothers warmth

\begin{tabular}{|c|c|c|c|c|c|c|c|}
\hline \multirow{2}{*}{ Perception of mother's support and understanding } & 1 & 2 & 3 & 4 & 5 & 6 & 7 \\
\hline & $f(\%)$ & $f(\%)$ & $f(\%)$ & $f(\%)$ & $f(\%)$ & $f(\%)$ & $f(\%)$ \\
\hline My mother knows how I feel & $0(.0)$ & $0(.0)$ & $3(6.4)$ & $3(6.4)$ & $7(14.9)$ & $11(23.4)$ & $23(48.9)$ \\
\hline My mother is trying to tell me how to live my life & $1(2.1)$ & $0(.0)$ & $0(.0)$ & $5(10.6)$ & $11(23.4)$ & $13(27.7)$ & $17(36.2)$ \\
\hline My mother finds time to talk to me. & $0(.0)$ & $2(2.1)$ & $0(.0)$ & $1(2.1)$ & $8(17.0)$ & $9(19.1)$ & $26(55.3)$ \\
\hline My mother accepts me and loves me for what I am. & $0(.0)$ & $0(.0)$ & $1(2.1)$ & $0(.0)$ & $6(12.8)$ & $5(10.6)$ & $35(74.5)$ \\
\hline My mother, whenever possible, allows me to do what I want & $6(12.8)$ & $4(8.5)$ & $2(4.3)$ & $6(12.8)$ & $11(23.4)$ & $7(14.9)$ & $11(23.4)$ \\
\hline My mother does not think of me often & $5(10.6)$ & $2(4.3)$ & $2(4.3)$ & $2(4.3)$ & $3(6.4)$ & $12(25.5)$ & $21(44.7)$ \\
\hline My mother clearly expresses love for me & $0(.0)$ & $0(.0)$ & $2(4.3)$ & $0(.0)$ & $8(17.0)$ & $10(21.3)$ & $27(57.4)$ \\
\hline $\begin{array}{l}\text { My mother listens to my opinion and attitude when I have a } \\
\text { problem }\end{array}$ & $0(.0)$ & $2(4.3)$ & $0(.0)$ & $2(4.3)$ & $9(19.1)$ & $14(29.8)$ & $20(42.6)$ \\
\hline My mother spends a lot of time with me & $1(2.1)$ & $1(2.1)$ & $2(4.3)$ & $3(6.4)$ & $17(36.2)$ & $11(23.4)$ & $12(25.5)$ \\
\hline My mother makes me feel special & $0(.0)$ & $0(.0)$ & $1(2.1)$ & $6(12.8)$ & $9(19.1)$ & $16(34.0)$ & $15(31.9)$ \\
\hline My mother allows me to decide on my own & $4(8.5)$ & $5(10.6)$ & $2(4.3)$ & $5(10.6)$ & $11(23.4)$ & $11(23.4)$ & $9(19.1)$ \\
\hline My mother often seems to busy to deal with me & $3(6.4)$ & $6(12.8)$ & $12(25.5)$ & $2(4.3)$ & $8(17.0)$ & $5(10.6)$ & $11(23.4)$ \\
\hline $\begin{array}{l}\text { My mother often disagrees with me and does not accept my } \\
\text { opinion. }\end{array}$ & $1(2.1)$ & $5(10.6)$ & $7(14.9)$ & $6(12.8)$ & $4(8.5)$ & $10(21.3)$ & $14(29.8)$ \\
\hline My mother insists that I do things her way & $6(12.8)$ & $3(6.4)$ & $8(17.0)$ & $4(8.5)$ & $9(19.1)$ & $8(17.0)$ & $9(19.1)$ \\
\hline My mother is not so concerned about my worries. & $3(6.4)$ & $5(10.6)$ & $4(8.5)$ & $5(10.6)$ & $6(12.8)$ & $11(23.4)$ & $13(27.7)$ \\
\hline My mother is usually happy to see me & $0(.0)$ & $2(4.3)$ & $0(.0)$ & $2(4.3)$ & $4(8.5)$ & $10(21.3)$ & $29(61.7)$ \\
\hline My mother is ready to look at things from my perspective & $2(4.3)$ & $3(6.4)$ & $0(.0)$ & $5(10.6)$ & $16(34.0)$ & $7(14.9)$ & $14(29.8)$ \\
\hline My mother invests time and energy in helping me. & $1(2.1)$ & $3(6.4)$ & $0(.0)$ & $4(8.5)$ & $9(19.1)$ & $8(17.0)$ & $22(46.8)$ \\
\hline My mother helps me choose my own way. & $4(8.5)$ & $1(2.1)$ & $0(.0)$ & $8(17.0)$ & $10(21.3)$ & $5(10.6)$ & $19(40.4)$ \\
\hline It seems to me that my mother is very disappointed in me. & $1(2.1)$ & $2(4.3)$ & $1(2.1)$ & $5(10.6)$ & $6(12.8)$ & $4(8.5)$ & $28(59.6)$ \\
\hline My mother is not too sensitive to many of my needs. & $3(6.4)$ & $9(19.1)$ & $6(12.8)$ & $6(12.8)$ & $3(6.4)$ & $4(8.5)$ & $16(34.0)$ \\
\hline
\end{tabular}

The frequency and the percentage of responses to individual claims show that deaf and hard-of-hearing students mostly perceive the involvement, autonomy support and warmth of their fathers (Table 2). 
In involvement, as well as for mothers, mostly but in small percentages, they consider that their fathers find time to talk (74.4\%) and spend enough time $(68.0 \%)$ with them, and that they are investing time and energy in helping them (76.6\%). About half of children think that fathers are often too busy to deal with them and that they are not much reliant on their worries and do not often think of them, but the answers are more favorable than for mothers.

In support of autonomy, deaf and hard-of-hearing students find that they (fathers), like mothers, but also at a lower percentage, know how they feel (97.2\%), allow them to do what they want $(65.9 \%)$, listen to their opinion and attitude when they have a problem $(65.0 \%)$, that they are willing to look through children's perspective $(68.0 \%)$, that they help them choose their own way $(72.3 \%)$, but also try to determine their way of life $(70.3 \%)$ and, at the smallest percentage, they are not too sensitive to their needs (23.4\%) and insist on doing things their way (42.5\%). In the case of warmth perceptions, they declare that their fathers accept and love them the way they are (91.4\%), that they clearly express their love towards them $(78.7 \%)$, make them feel special $(72.3 \%)$, that they are usually happy to see them $89.3 \%$ ), and at the lowest rate they often disagree with them $(31.9 \%)$ and do not accept their opinion. However, as with mothers, with a slightly higher percentage $(85.1 \%)$, the respondents said that they felt that their fathers were very disappointed in them.

Table 2. Distribution of responses to perception of involvement, support of autonomy and fathers warmth

\begin{tabular}{|c|c|c|c|c|c|c|c|}
\hline \multirow{2}{*}{ Perception of father's support and understanding } & 1 & 2 & 3 & 4 & 5 & 6 & 7 \\
\hline & $\mathrm{f}(\%)$ & $f(\%)$ & $f(\%)$ & $f(\%)$ & $f(\%)$ & $f(\%)$ & $\mathrm{f}(\%)$ \\
\hline My father knows how I feel & $1(2.1)$ & $1(2.1)$ & $3(6.4)$ & $4(8.5)$ & $7(14.9)$ & $10(21.3)$ & $21(44.7)$ \\
\hline My father is trying to tell me how to live my life & $2(4.3)$ & $3(6.4)$ & $2(4.3)$ & $7(14.9)$ & $10(21.3)$ & $10(21.3)$ & $13(27.7)$ \\
\hline My father finds time to talk to me. & $4(8.5)$ & $2(4.3)$ & $3(6.4)$ & $3(6.4)$ & 11(23.4) & $9(19.1)$ & 15(31.9) \\
\hline My father accepts me and loves me for what I am. & $0(.0)$ & $1(2.1)$ & $2(4.3)$ & $1(2.1)$ & $9(19.1)$ & $5(10.6)$ & $29(61.7)$ \\
\hline My father, whenever possible, allows me to do what I want & $3(6.4)$ & $9(19.1)$ & $2(4.3)$ & $2(4.3)$ & $14(29.8)$ & $9(19.1)$ & $8(17.0)$ \\
\hline My father does not think of me often & $5(10.6)$ & $8(17.0)$ & $2(4.3)$ & $4(8.5)$ & $3(6.4)$ & $9(19.1)$ & $16(34.0)$ \\
\hline My father clearly expresses love for me & $3(6.4)$ & $2(4.3)$ & $1(2.1)$ & $4(8.5)$ & $8(17.0)$ & $13(27.7)$ & $16(34.0)$ \\
\hline $\begin{array}{l}\text { My father listens to my opinion and attitude when I have a } \\
\text { problem }\end{array}$ & $1(2.1)$ & $2(4.3)$ & $3(6.4)$ & $1(2.1)$ & $12(25.5)$ & $12(25.5)$ & $16(34.0)$ \\
\hline My father spends a lot of time with me & $5(10.6)$ & $4(8.5)$ & $3(6.4)$ & $3(6.4)$ & $12(25.5)$ & $7(14.9)$ & $13(27.7)$ \\
\hline My father makes me feel special & $2(4.3)$ & $3(6.4)$ & $1(2.1)$ & $7(14.9)$ & $6(12.8)$ & $12(25.5)$ & $16(34.0)$ \\
\hline My father allows me to decide on my own & $6(12.8)$ & $4(8.5)$ & $6(12.8)$ & $0(.0)$ & $15(31.9)$ & $7(14.9)$ & $9(19.1)$ \\
\hline My father often seems to busy to deal with me & $8(17.0)$ & $7(14.9)$ & $4(8.5)$ & $4(8.5)$ & $12(25.5)$ & $4(8.5)$ & $8(17.0)$ \\
\hline $\begin{array}{l}\text { My father often disagrees with me and does not accept my } \\
\text { opinion. }\end{array}$ & $13(27.7)$ & $7(14.9)$ & $6(12.8)$ & $6(12.8)$ & $10(21.3)$ & $4(8.5)$ & $1(2.1)$ \\
\hline My father insists that I do things her way & $2(4.3)$ & $7(14.9)$ & $13(27.7)$ & $5(10.6)$ & $5(10.6)$ & $5(10.6)$ & $10(21.3)$ \\
\hline My father is not so concerned about my worries. & $5(10.6)$ & $4(8.5)$ & $11(23.4)$ & $3(6.4)$ & $4(8.5)$ & $8(17.0)$ & $12(25.5)$ \\
\hline My father is usually happy to see me & $2(4.3)$ & $1(2.1)$ & $1(2.1)$ & $1(2.1)$ & $6(12.8)$ & $9(19.1)$ & $27(57.4)$ \\
\hline My father is ready to look at things from my perspective & $5(10.6)$ & $0(.0)$ & $1(2.1)$ & $9(19.1)$ & $16(34.0)$ & $5(10.6)$ & $11(23.4)$ \\
\hline My father invests time and energy in helping me. & $3(6.4)$ & $5(10.6)$ & $0(.0)$ & $3(6.4)$ & $10(21.3)$ & $7(14.9)$ & 19(40.4) \\
\hline My father helps me choose my own way. & $6(12.8)$ & $0(.0)$ & 2(4.3) & $5(10.6)$ & $12(25.5)$ & $8(17.0)$ & $14(29.8)$ \\
\hline It seems to me that my father is very disappointed in me. & $3(6.4)$ & $1(2.1)$ & $0(.0)$ & $3(6.4)$ & $3(6.4)$ & $10(21.3)$ & $27(57.4)$ \\
\hline My father is not too sensitive to many of my needs. & $21(44.7)$ & $10(21.3)$ & $1(2.1)$ & $4(8.5)$ & $4(8.5)$ & $3(6.4)$ & $4(8.5)$ \\
\hline
\end{tabular}

Given the need for early intervention and intensive rehabilitation treatment, the parents of deaf and hardof-hearing children have been forced to be involved in these processes since the early developmental period, and therefore their support is indispensable, which largely determines their positive perception by children.

Sremić and Rijavec (2010) investigating the interrelationship between perceptions of parental behavior (through perceived parental involvement, support of autonomy and warmth, especially for the mother and especially for the father) and school achievement of hearing students in seventh and eighth grade, on a sample of 179 students, received results that indicate that the dimensions of parental behavior are significantly associated with all school achievement measures.

A finding by Toscano, McKee and Lepoutre (2002) according to Marschark, Convertino and LaRock (2006) similarly found that deaf college students who demonstrated high academic literacy skills tended to have parents who were very involved in their early educations, effective family communication (regardless of mode), and high expectations on the part of their parents. 
Sremić and Rijavec (2010) cited researches that have shown great importance to parent involvement, a high level of involvement is associated with competence and motivation for achievement (Pulkkinen, 1982), a positive correlation between parental involvement in school activities and school achievement (Stevenson \& Baker, 1987), and on this basis they point out the assumption that children of involved parents feel more competent, have greater self-control and independent academic motivational orientation.

„The study's findings indicate that although parental involvement in their deaf child's school-based education program can positively contribute to academic performance, parental communication skill is a more significant predictor for positive language and academic development. Factors associated with parental involvement, maternal communication, and use of additional services are explored and suggestions are offered to enhance parental involvement and communication skills" (Calderon, 2000, p. 140).
Suzić's (2005) research on the relationship between parents and students aspiration to school achievement has shown that parents and children have quite different views of the same interpersonal relationship and that what parents think of as help and support are often seen by children as a denial of freedom, control or discipline. The same author states that "aspirations of parents sometimes disturb the interest of their children for school achievement, but it happens that these aspirations help the student's efforts and strengthen their motivation" (Suzić, 2005, p. 369).

Parental aspirations can affect the child's professional self-efficacy and school achievement (Jen-Yi \& Li Li, 2011; see Milanović-Dobrota \& Radić-Šestić, 2012). By testing differences in the perception of involvement, support of autonomy and warmth of the mothers in relation to the fathers by deaf and hard-ofhearing students, the t-test determined a significant difference $(\mathrm{t}=5.37 ; \mathrm{p}=.000)$ in favor of the mothers (Table 3).

Table 3. $t$-test difference in perception of parental support and understanding

\begin{tabular}{cccccccc}
\hline Perception of parental support and understanding & MIN & MAX & M & SD & $t$ & $d f$ & $p$ \\
\hline Perception of the Mothers & 74 & 139 & 114.70 & 15.01 & \multirow{2}{*}{5.37} & 46 & $\mathbf{. 0 0 0}$ \\
Perception of the Fathers & 50 & 130 & 103.30 & 17.82 & & \\
\hline
\end{tabular}

When examining parenting styles of support, researchers often used children's parent perceptions. The results have shown that mothers are more perceived as supportive than fathers (Grolnick, Ryan, \& Deci, 1991). Bodner-Johnson (1986, see Marschark, Convertino, \& Larock, 2006) investigated family factors in deaf students' academic achievement. Through interviews with parents, she identified two significant predictors: acceptance of the child's hearing loss (including a positive view of the Deaf community) and high expectations for their children.

Acceptance may also be a cause of poorer support and understanding of fathers. However, practice has also shown that the father most often takes care of the existence and the mother of a continuous rehabilitationeducation process, which in the end can affect father's inferior involvement, and thus lead to poorer parent support for autonomy and warmth.

A study exploring paternal-child characteristics indicated that the father's resistance to accepting deafness was associated with poor language outcomes in the deaf child (Hadadian \& Rose, 1991; see Kushalnagar et al., 2007, p. 337)

In order to prevent or alleviate the developmental difficulties of deaf and hard-of-hearing children, adequate approach within the family is necessary as well as in the choice of communication system with the child and in the acceptance of the child. From the early age of parent-child interaction, children begin to perceive themselves and others. The parent should be based on the development of potential in the child, not on its weaknesses and difficulties. Emotional support and social approval by the parents is essential to building an image of oneself, forming interests, wishes, attitudes, goals, which together affects children's perception of their own opportunities and ways to face challenges.

\section{CONCLUSION}

Taking into account the need for early intervention, the parents of deaf and hard-of-hearing children have been forced to be involved in this process since the early developmental period. Their support is indispensable which, to the greatest extent by these students in this research, determines a positive perception of involvement, support of autonomy and warmth of both parents. The obtained differences in a more positive perception of mothers, as compared to their father, appear to be objective and realistic since practice has shown that the father most often takes care of the existence and the mother of a continuous rehabilitation-education process. 
In order to prevent or alleviate the difficulties of any kind, a deaf and hard-of-hearing child should have adequate approach within the family, both in choosing a communication system with a child and in accepting a child. In a parent-child interaction, children begin to perceive themselves and others. The parent should base his/her involvement on developing and improving the potential of the child, not its weaknesses and difficulties. It is essential for parental support and understanding to be more focused on involving the student in appropriate activities and relegating the set goals and tasks in them. Emotional sympathy and social stimulation must be an integral part of parents' support for the deaf and hard-of-hearing child to build up a better image of themselves, forming interests, desires, attitudes, goals, and thus having a positive perception of their own potential and facing various challenges.

\section{REFERENCES}

Ahlert, I. A., \& Greeff, A. P. (2012). Resilience factors associated with adaptation in families with deaf and hard of hearing children. American Annals of the Deaf, 157(4), 391-404. doi: 10.1353/aad.2012.1629.

Andreeva, A., Celo, P., \& Vian, N. (2017). Play in children with hearing impairments. In: S., Besio, D, Bulgarelli, V. Stancheva-Popkostadinova, Play development in children with disabilties (pp. 94-101). De Gruyter Open. doi: 10.1515/9783110522143-008.

Calderon, R. (2000). Parental involvement in deaf children's education programs as a predictor of child's language, early reading, and social-emotional development. Journal of deaf studies and deaf education, 5(2), 140-155. doi: 10.1093/deafed/5.2.140

Grolnick, W. S., Ryan, R. M., \& Deci, E. L. (1991). Inner resources for school achievement: Motivational mediators of children's perceptions of their parents. Journal of educational psychology, 83(4), 508. doi: 10.1037/00220663.83.4.508.

Hintermair, M. (2006). Parental resources, parental stress, and socioemotional development of deaf and hard of hearing children. Journal of Deaf Studies and Deaf Education, 11, 493-513. doi: 10.1093/deafed/en1005.

Jackson, C. W., \& Turnbull, A. P. (2004). Impact of deafness on family life: A review of the literature. Topics in Early Childhood Special Education, 24(1), 15-29. http:// dx.doi.org/10.1177/02711214040240010201.
Jacobs, P. (2010). Psychosocial potential maximisation: A framework of proactive psychosocial attributes and tactics used by individuals who are deaf. The Volta Review, 110(1), 5-29.

Kushalnagar, P., Krull, K., Hannay, J., Mehta, P., Caudle, S., \& Oghalai, J. (2007). Intelligence, parental depression, and behavior adaptability in deaf children being considered for cochlear implantation. Journal of deaf studies and deaf education, 12(3), 335-349. doi:10.1093/ deafed/enm006.

Kushalnagar, P., Topolski, T. D., Schick, B., Edwards, T. C., Skalicky, A. M., \& Patrick, D. L. (2011). Mode of communication, perceived level of understanding, and perceived quality of life in youth who are deaf or hard of hearing. Journal of Deaf Studies and Deaf Education, 16(4), 512-523. doi:10.1093/deafed/enr015.

Marschark, M., Convertino, C. i Larock, D. (2006). Optimizing Academic Performance of Deaf Students: Access, Opportunities, and Outcomes. In: F. C. Moores \& S. D. Martin (Eds.). Deaf Learners Developments in Curriculum and Instruction (pp. 179-201). Washington, D.C. 20002: Gallaudet University Press.

Milanović-Dobrota, B. Z., \& Radić-Šestić, M. (2012). Značaj modela samoefikasnosti u vaspitno-obrazovnom radu sa adolescentima [Significance of self-efficacy model in educational work with adolescents]. Specijalna edukacija i rehabilitacija, 11(4), 637-655. doi: 10.5937/ specedreh11-3104.

Nicholas, J. G., \& Geers, A. E. (2006). Effects of early auditory experience on the spoken language of deaf children at 3 years of age. Ear and hearing, 27(3), 286-298. doi: 10.1097/01.aud.0000215973.76912.c6.

Olaosun, A. O., \& Ogundiran, O. (2013). Assistive Technology For Hearing and Speech Disorders. Journal of Biology, Agriculture and Healthcare, 3(17). Retrieved from https://iiste.org/Journals/index.php/JBAH/article/download $/ 8963 / 9133$

Sremić, I., \& Rijavec, M. (2010). Povezanost percepcije majčinog $\mathrm{i}$ očevog roditeljskog ponašanja i školskog uspjeha kod učenika osnovne škole. Educational Sciences/Odgojne Znanosti, 12(2). Retrieved from https:// hrcak.srce.hr/68277

Suzić, N. (2005). Pedagogija za XXI vijek. Banja Luka: TTCentar.

Szarkowski, A. \& Brice, P. J. (2016). Hearing Parents' Appraisals of Parenting a Deaf or Hard-of-Hearing Child: Application of a Positive Psychology Framework. The Journal of Deaf Studies and Deaf Education, 21 (3), 249-258, https://doi.org/10.1093/deafed/enw007. 